\title{
Algoritma Extended Weighted Tree Similarity untuk Memberikan Solusi Memasak pada J2ME
}

\author{
${ }^{1}$ Yosephine Halim, ${ }^{2}$ Ramos Somya, ${ }^{3}$ Charitas Fibriani \\ ${ }^{1}$ Program Studi Teknik Informatika, Fakultas Teknologi Informasi, Univers itas Kristen Satya \\ Wacana, Jl. Diponegoro 52-60 Salatiga, Yuke_chan_gir1@yahoo.com, \\ ${ }^{2}$ Program Studi Teknik Informatika, Fakultas Teknologi Informasi, Universitas Kristen Satya \\ Wacana, Jl. Diponegoro 52-60 Salatiga, ramos.6005@gmail.com, \\ ${ }^{3}$ Program Studi Teknik Informatika, Fakultas Teknologi Informasi, Universitas Kristen Satya \\ Wacana, Jl. Diponegoro 52-60 Salatiga, charitasfibriani@ yahoo.com
}

\begin{abstract}
The aim of this thesis is to give the simplicity in cooking with limited ingredients for the users by using mobile technology (J2ME). The aim of this thesis can be done by using Extended Weighted Tree Similarity Algorithm, a calculation to find out the highest weight similarity between the menu which has been inputted in the application as a database; and the inputted ingredients from the users of this application. The conclusion of this thesis is that Algorithm Extended Weighted Tree Similarity can be implemented into mobile technology (J2ME).
\end{abstract}

Keywords: extended weighted tree similarity, cooking smart, J2ME

\begin{abstract}
Abstrak
Tujuan dari penelitian ini adalah memberikan kemudahan dalam memasak dengan bahan yang terbatas bagi pengguna dengan menggunakan teknologi mobile (J2ME). Tujuan dari tesis ini dapat dilakukan dengan menggunakan Algoritma Extended Weighted Tree Similarity, perhitungan untuk mengetahui kesamaan bobot tertinggi antara menu yang telah diinput dalam aplikasi sebagai database, dan bahanbahan dimasukkan dari pengguna aplikasi ini. Kesimpulan dari tesis ini adalah bahwa Algoritma Extended Weighted Tree Similarity dapat diimplementasikan ke dalam teknologi mobile (J2ME).
\end{abstract}

Kata Kunci : extended weighted tree similarity, cooking smart, J2ME

\section{Pendahuluan}

Resep masakan pada umumnya menggunakan media cetak/buku. Buku tersebut berisi panduan memasak untuk berbagai macam masakan. Panduan tersebut memudahkan untuk memasak berbagai jenis masakan, namun dalam mencari satu resep masakan mendapat kesulitan dalam mencari dan hanya dipermudah dengan membaca indeks resep masakan. Hal ini menyebabkan penggunaan waktu yang kurang efisien untuk mencari satu jenis menu masakan.

Pada penelitian kali ini, resep masakan akan diterapkan pada cooking smart. Perbedaan dengan panduan resep masakan biasa adalah terdapat fitur yang memudahkan user dalam mencari resep masakan. Hanya dengan milih bahan yang dimiliki atau dikehendaki, resep masakan pun bisa didapatkan berdasarkan bahan tersebut.

Pemberian solusi memasak pada penelitian ini, menggunakan algoritma Extended Weighted Tree Similarity, di mana proses pencarian dilakukan bukan dengan ditemukannya inputan user saja, melainkan dengan melakukan perhitungan tingkat kemiripan pohon utama dengan inputan user. Pohon utama tersebut dibuat terlebih dahulu sebagai panduan dalam perhitungan. Penggunaan algoritma Extended Weighted Tree Similarity pada penelitian ini, yaitu dengan membandingkan kemiripan antara menu masakan yang telah ada dan menu masakan yang diinputkan oleh user. Metode ini disusun berdasarkan tree yang memiliki node berlabel, cabang berlabel serta berbobot.

Penelitian ini menggunakan J2ME sebagai pengimplementasi dari cooking smart yang menggunakan Extended Weighted Tree Similarity. Hal ini dikarenakan mayoritas platform 
mobile device masih menggunakan platform java. Tujuan lain adalah untuk membuat kemudahan dalam membawa dan membuka resep masakan di mana pun dan kapan pun.

\section{Tinjauan Pustaka}

\section{Extended Weighted Tree Similarity}

Tingkat kemiripan pada algoritma Extended Weighted Tree Similarity ditentukan dalam range nilai 0 sampai dengan 1 . Kemiripan suatu keyword dilihat dari bagaimana hasil perhitungan. Apabila perhitungan tersebut mendekati nilai 1, hasil yang didapat adalah keyword tersebut memiliki tingkat kemiripan yang hampir sama. Sebaliknya, perhitungan mendeketi nilai 0 , keyword tersebut tingkat kemiripannya berbeda dengan informasi yang telah ada. Algoritma ini menggunakan representasi tree sebagai input untuk mengkalkulasi derajat kemiripan antara 2 objek [1].

Dalam pencarian semantik yang menggunakan algoritma weighted tree similarity, metadata disusun berdasarkan tree yang memiliki node berlabel, cabang berlabel serta berbobot. Struktur metadata tree disusun berdasarkan informasi semantik semacam taksonomi, ontologi, preference, sinonim, homonim, dan stemming. Oleh karena itu, metadata yang digunakan dapat lebih merepresentasikan isi sebuah artikel serta hasil pencarian dapat lebih tepat (precision).

Algor itma weighted tree similarity memiliki keunikan karena memiliki representasi tree yang berbeda dengan yang lain. Tree yang dipergunakan memiliki node berlabel, cabang berlabel serta berbobot. Cabang yang berlabel memberikan pemahaman lebih kepada label nodenya. Begitu pula bobot cabang memungkinkan memberikan tingkat kecenderungan kepada cabang tertentu lebih dari yang lain.

Nilai kemiripan tiap pasangan subtree berada diantara nilai 0 dan 1 . Nilai 0 bermakna berbeda sama sekali sedangkan 1 bermakna identik. Kedalaman (depth) dan lebar (breadth) tree tidak dibatasi. Algoritma penghitung kemiripan tree secara rekursif menjelajahi tiap pasang tree dari atas ke bawah mulai dari kiri ke kanan. Algoritma mulai menghitung kemiripan dari bawah ke atas ketika mencapai leaf node.

Nilai kemiripan tiap pasang subtree di level atas dihitung berdasar kepada kemiripan subtree di level bawahnya. Sewaktu penghitungan, kontribusi bobot cabang juga diperhitungkan [2].

Suatu tree terdiri dari 1 atau lebih parent yang masing-masing dapat memiliki atribut berupa bobot serta nama parent. Setiap parent terdiri identifier, yang mempunyai atribut bobot [1].

Keseluruhan tree direpresentasikan dengan menggunakan fungsi vector dan perhitungannya dengan cara membandingkan antara isi vector utama yang berupa tree dengan vector inputan dari user. Apabila sama, maka dilakukan perkalian sesuai dengan bobot vector inputan dan bobot vector utama. Gambar 1 merupakan contoh representasi tree berita tentang gempa bantul.

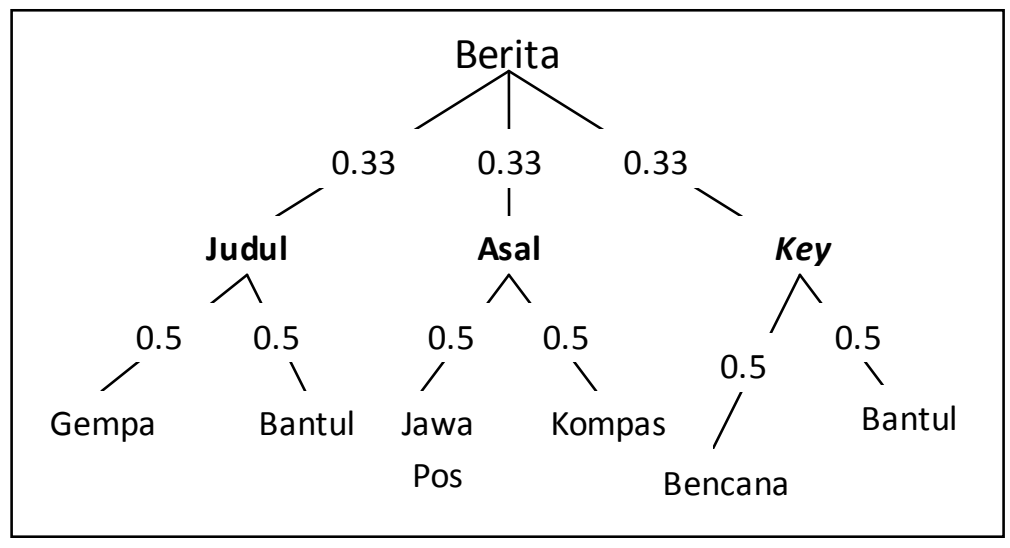

Gambar 1 Contoh Repesentasi Tree [1] 
Sebuah tree berita memiliki dari tiga parent yaitu, judul, asal, dan key. Masing-masing parent memiliki bobot, yang jika dijumlahkan akan bernilai 1 . bobot masing-masing parent diperoleh dari persamaan (1).

$$
W_{i}=1 / n
$$

dimana

$W_{i} \quad$ : bobot parent ke-I, $n \quad$ : total parent yang ada

Setiap parent memiliki anak yang disebut dengan identifier. Berdasarkan Gambar 1, yang menjadi identifier dari parent judul adalah gempa dan bantul. Identifier dari parent asal adalah jawa pos dan kompas, sedangkan identifier untuk parent key adalah bencana dan bantul. Setiap identifier juga memiliki bobot yang diperoleh dari persamaan (2).

$$
W_{\text {ind }}=\text { frek } / n
$$

dimana:

$W_{\text {ind }} \quad$ : bobot identifier ke- $i$

frek : jumlah kemunculan identifier

$n \quad$ : total identifier yang ada

Setelah menemukan bobot parent dan identifier, dapat dilakukan langkah selanjutnya dengan mengetahui tree inputan dari user.

Dengan membandingkan dua tree yang memiliki nama parent yang sama, perhitungan tingkat kemiripan dapat dilakukan. Perhitungan dilakukan dengan membandingkan tiap parent yang sama beserta dengan identifier yang dimilikinya [1]. Perhitungan tersebut dapat dilihat pada persamaan (3).

$$
B K=\sum\left(\left(W_{(i)} * W_{(j)}\right) *\left(\sum W_{\text {ind(i) }} * W_{\text {ind(j) }}\right)\right)
$$

dimana:

$B K \quad$ : bobot kemiripan

$W_{(i)} \quad$ : bobot parent utama ke-i

$W_{(j)} \quad$ : bobot parent inputan ke-j

Wind $_{(i)} \quad$ : bobot identifier utama ke-i

Wind $_{(j)} \quad$ : bobot identifier inputan ke-j

Pada kondisi nyata proses pencocokan tidak selalu akan menemukan kesamaan baik pada label root maupun pada label node. Gambar 4 adalah pasangan tree yang memiliki label root sama tetapi label node berbeda serta pasangan tree yang memiliki label root dan label node berbeda. Penjelasan tersebut dapat dilihat pada Gambar 2 [3].

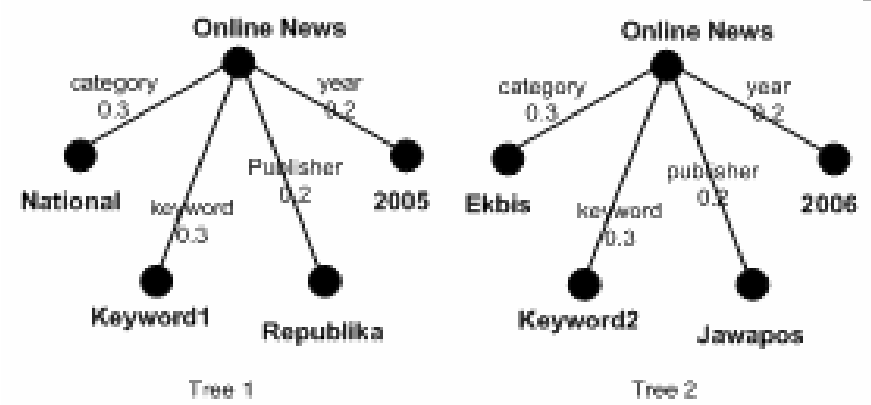

Gambar 2 Pasangan Tree yang Memiliki Label Root Sama tetapi Label Node Berbeda[3] 
Pada Gambar 2 dan Gambar 3, label node untuk kedua pasangan tree itu berbeda sehingga similarity kedua pasangan tree ini berdasarkan label node adalah 0. Akan tetapi, jika perhitungan nilai similarity juga melibatkan unsur label root maka secara logika pasangan tree pada Gambar 2 masih memiliki kesamaan dibandingkan dengan pasangan tree pada Gambar 3 [3]
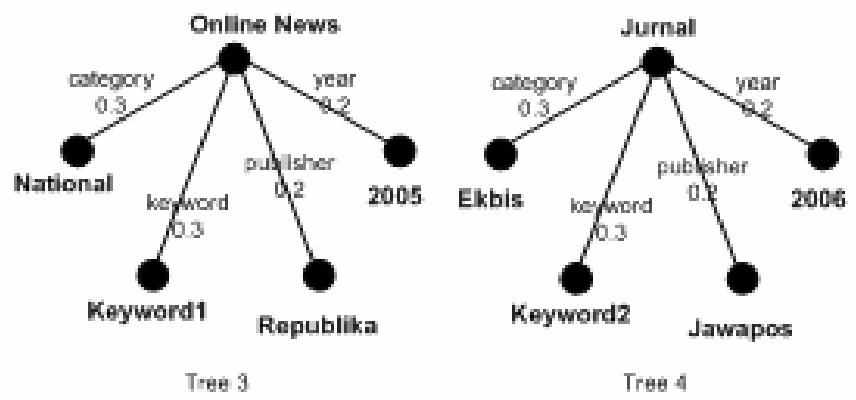

Gambar 3 Pasangan Tree yang Memiliki Label Root dan Label Node Berbeda [3]

Pada kasus ini Algoritma Extended Weighted Tree similarity memberikan nilai NodeIndentity Fraction $(N)$ untuk pasangan tree pertama sebesar 0,1 dan nilai $\mathrm{N}$ untuk pasangan tree kedua sebesar 0 . Kasus tertentu, pemberian bobot juga berpengaruh pada hasil similarity, terdapat dua pohon yaitu pohon $\mathrm{x}$ dan pohon $\mathrm{y}$. pada pohon $\mathrm{x}$ terdapat label root dan label node yang berbeda. Penjelasan ini dapat dilihat pada Gambar 4 [3].

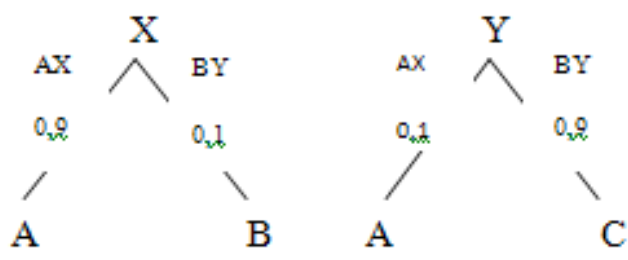

Gambar 4 Pasangan Tree yang Memiliki Bobot yang Berbeda [3]

Similarity kedua label pada cabang "AX" adalah 1 karena keduanya sama, sedangkan cabang "BY" yang punya label berbeda adalah 0 . Total Nilai similarity adalah nilai similarity didapat dari perhitungan yang dapat dilihat pada perhitungan (3).

$$
\begin{aligned}
& \operatorname{Similarity}(X, Y)=\operatorname{sim}(" A \text { ". " } A \text { ") }) \text { [( bobot " } A X \text { " + bobot " } A X \text { ") } / 2]+ \\
& \operatorname{sim}(\text { "B"," } C \text { ") * [(bobot "BY" + bobot "BY") /2] }
\end{aligned}
$$

Hasil pengamatan ini menunjukkan bahwa nilai similarity dua tree yang memiliki label node persis sama menyebabkan distribusi bobot cabangnya tidak berpengaruh terhadap nilai similarity. Nilai bobot akan memiliki pengaruh jika ada perbedaan nilai minimal pada salah satu cabangnya [3].

\section{Java 2 Micro Edition}

Komponen-komponen J2ME terdiri dari Java Virtual Machine (JVM) yang digunakan untuk menjalankan aplikasi Java pada emulator atau handheld device, Java API (Application Programming Interface) dan tools lain untuk pengembangan aplikasi Java semacam emulator Java Phone, emulator Motorolla dari J2ME wireless toolkit. Dalam pengembangan aplikasi wireless dengan Java, J2ME dibagi menjadi dua buah bagian diantaranya ialah bagian configuration dan profile [4].

J2ME merupakan tulang punggung bagi perkembangan teknologi m-commerce saat ini. Beberapa keunggulan dari useran J2ME adalah (1) Menciptakan aplikasi yang bersifat portable, (2) Sistem keamanan yang baik, (3) Aplikasi bisa digunakan dalam mode offline ataupun online, 
(4) Aplikasi mengadopsi karakteristik utama Java, yaitu "Write once, run anywhere, any time, and over any device" [5].

Di dalam mengembangkan aplikasi Java, J2ME sesungguhnya merupakan bagian integral dari Java 2 Standard Edition atau sering disebut J2SE. Oleh karena J2ME merupakan subset dari J2SE, maka tidak semua library J2SE dapat digunakan pada J2ME. Namun sebaliknya, Sun mengembangkan library khusus, di mana library ini tidak ada pada J2SE. Dalam implementasinya teknologi J2ME memiliki batasan terutama yang berkaitan dengan perangkat keras, merek mobile phone, atau kemampuan mobile phone tersebut.

Di dalam J2ME telah didefinisikan dua konfigurasi. Konfigurasi pertama adalah Connected Limited Device Configuration atau disingkat CLDC, dan konfigurasi yang kedua adalah Connected Device Configuration atau disingkat CDC. CLDC adalah konfigurasi J2ME yang ditujukan untuk mengembangkan aplikasi Java dengan perangkat mobile yang kecil dengan ukuran memori 160KB sampai 512KB dan processor 16/32 bit. Sedangkan CDC adalah konfigurasi J2ME yang ditujukan untuk perangkat mobile yang lebih besar dengan memori minimal 2MB dan ber-processor 32bit.

Di dalam J2ME terdapat 2 macam profile yaitu MIDP (Mobile Information Device Profile) untuk CLDC dan Foundation Profile untuk CDC. Profile di dalam J2ME berperan sebagai layer yang menyediakan fungsi API kepada programmer yang membuat aplikasi Java yang berja lan di atasnya. Configuration juga menyediakan API seperti profile, hanya saja fungsi API di level configuration tidak direkomendasikan untuk diakses oleh programmer secara langsung. Configuration bersama dengan profile pada akhirnya menciptakan J2ME runtime environment. Arsitektur dari J2ME secara umum dan khusus dapat dilihat pada Gambar 5 [6].

Aplikasi yang berjalan pada sebuah perangkat yang mendukung MIDP disebut dengan MIDlets, atau lebih singkatnya MIDlet merupakan aplikasi yang dibuat menggunakan Java 2 Micro Edition dengan profile Mobile Information Device Profile (MIDP). MIDP dikhususkan untuk digunakan pada handset dengan kemampuan CPU, memori, keyboard dan layer yang terbatas, seperti handphone, pager, PDA dan sebagainya [4].
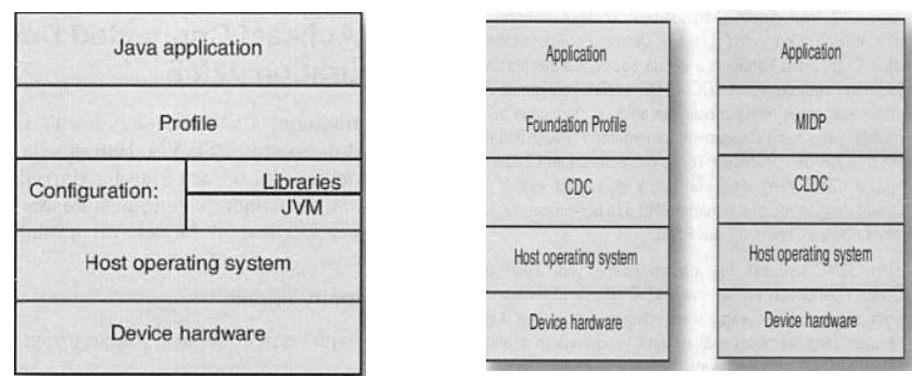

Gambar 5 Arsitektur J2ME Secara Umum dan khusus [6]

MIDlet memiliki struktur direktori sebagai berikut:

1. Src, menyimpan source code untuk MIDlet dan kelas lain yang diperlukan.

2. Res, menyimpan sumber daya yang dibutuhkan oleh MIDlet, misalnya gambar icon.

3. Lib, menyimpan file JAR atau ZIP yang berisi library tambahan yang dibutuhkan MIDlet.

4. Bin, menyimpan file JAR, JAD danfile manifest yang berisi muatan komponen MIDlet [7].

\section{Metode Perancangan}

Metode yang akan digunakan pada sistem ini menggunakan Metode Prototyping Model. Metode ini merupakan proses iteratif da lam pengembangan sistem di mana kebutuhan diubah ke dalam sistem yang bekerja (working system) yang secara terus menerus diperbaiki melalui kerjasama antara user dan analis. Prototype juga bisa dibangun melalui beberapa tool pengembangan untuk menyederhanakan proses. Prototyping merupakan bentuk Rapid Application Development (RAD). RAD memiliki beberapa kelemahan, di antaranya (1) RAD mungkin mengesampingkan prinsip-prinsip rekayasa perangkat lunak, (2) Menghasilkan 
inkonsistensi pada modul-modul system, (3) Tidak cocok dengan standar, (4) Kekurangan prinsip reusability komponen [8].

Metode Prototyping model dapat dilihat pada Gambar 6.

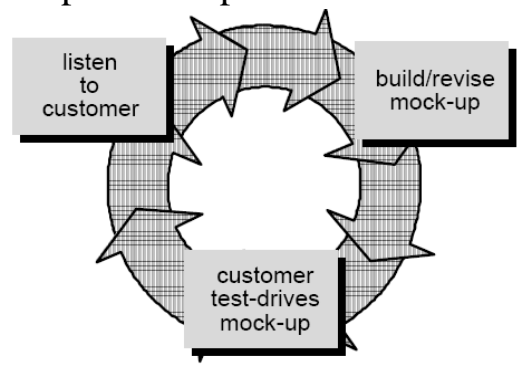

Gambar 6 Metode Pengembangan Prototyping [8]

Tahapan pada prototyping adalah sebagai berikut:

1. Analis bekerja dengan tim untuk mengidentifikasi kebutuhan awal untuk sistem.

2. Langkah selanjutnya adalah membuat prototype. Ketika prototype telah selesai, user bekerja dengan prototype itu dan menyampaikan pada analis apa yang mereka sukai dan tidak mereka sukai.

3. Analis menggunakan feedback ini untuk memperbaiki prototype.

4. Versi baru diberikan kembali ke user.

Ulangi langkah-langkah tersebut sampai user merasa puas.

Pada model prototype memiliki beberapa keuntungan seperti, melibatkan user dalam analisis dan desain, memiliki kemampuan menangkap kebutuhan secara kongkret daripada abstrak. Prototype dapat digunakan secara standalone dan dapat memperluas SDLC (System development life cycle) [8].

\section{Tahapan Metode Prototyping}

Tahapan-tahapan prototype dalam penelitian ini dinyatakan telah sesuai dengan kebutuhan user pada prototype kedua. Tahapan-tahapan tersebut yaitu :

\section{Prototyping 1}

Tahapan awal analis mengumpulkan data awal yang berdasarkan pada keinginan dari user. Pengumpulan data tersebut diambil dari kuisioner yang disebar sebanyak 30 lembar. Penyebaran kuisioner tersebut dikategorikan berdasarkan jenis kelamin wanita dan umur antara 17-25 tahun. Hasil dari kuisioner tersebut diketahui; umumnya wanita tidak menyukai memasak dan lebih suka untuk membeli masakan yang telah saji, dan kesulitan dalam menentukan menu masakan yang cocok dengan bahan yang dimiliki.

Setelah melakukan kuisioner, tahapan selanjutnya dalam metode prototyping yaitu build/revise mock-up atau membangun aplikasi secara cepat. Dalam tahap ini dihasilkan aplikasi cooking smart prototype pertama dihasilkan proses memasuki tahapan selanjutnya yaitu customer test driver mock-up. Pada tahap ini aplikasi cooking smart dapat diserahkan kepada user untuk dievaluasi untuk mengetahui kekurangan dan kendala-kendala pada prototype pertama.

\section{Prototyping 2}

Pada tahap penyerahan prototype pertama didapatkan informasi baru tentang kebutuhan aplikasi yang akan dibangun nantinya, didapat kebutuhan sistem dari hasil kuisioner tahap dua yaitu (1) Aplikasi dapat menyimpan menyimpan sejumlah resep masakan, (2) Bahan masakan yang dipakai berdasarkan gizi masakan, yaitu karbohidrat, protein, dan vitamin mineral, (3) Aplikasi dapat memberikan solusi berdasarkan bahan yang dimiliki/dikehendaki.

Setelah mendapatkan informasi baru tentang kebutuhan aplikasi cooking smart, dapat dikembangkan aplikasi cooking smart prototype pertama sesuai dengan hasil evaluasi tersebut menjadi prototype kedua. Pada pembangunan prototype kedua aplikasi ditekankan pada pemberian solusi memasak berdasarkan bahan. Selain aplikasi cooking smart memanfaatkan teknologi mobile yaitu J2ME, sebagai sarana pengembangannya. Hasil dari prototype kedua 
dievaluasi kembali dan telah memenuhi kebutuhan dari user yang umumnya wanita muda. Dan tahapan dari prototyping berakhir pada protoype kedua dikarenakan hasil aplikasi telah memenuhi kebutuhan $u$ ser.

Perancangan analisa sistem Cooking Smart menggunakan metode UML (Unified Modelling Language) akan dipaparkan sebagai berikut:

\section{Use Case Diagram}

User yang menggunakan aplikasi ini memiliki dua aktivitas. Aktivitas pertama, user dapat memilih menu masakan. Namun dalam menu masakan, user pasti melihat menu masakan tersebut. Aktivitas kedua, user dapat memilih bahan masakan. Pada saat user telah memilih bahan masakan, user dapat melihat bahan masakan tersebut sebelum pada akhirnya menjalankan algoritma untuk mendapatkan solusi memasak. Penjelasan singkat di atas dapat dilihat pada Gambar 7.

\section{Class Diagram}

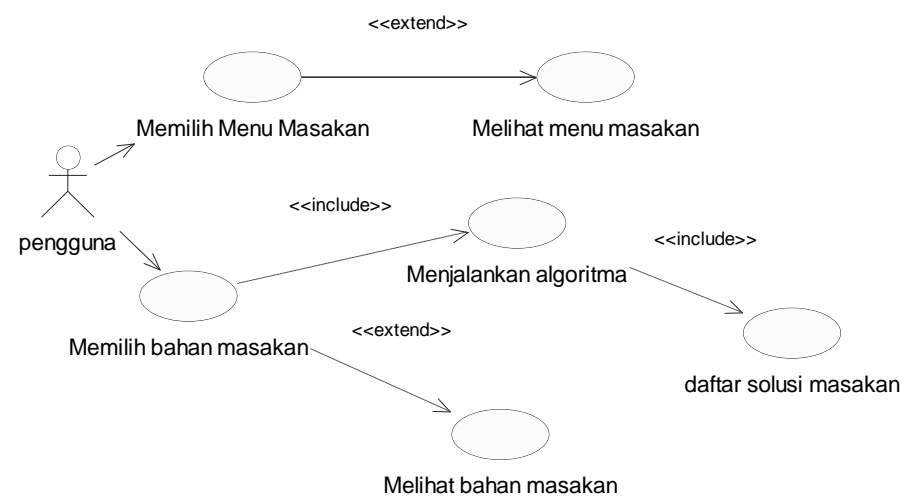

Gambar 7 Use Case Diagram

Pada class diagram dijelaskan alur data yang ada pada aplikasi ini. Terdapat data masakan yang berisi nama masakan dan nilai masakan. Tujuan dari nilai masakan adalah untuk menyimpan nilai masakan yang tertinggi dan berguna untuk memberikan solusi yang terbaik. Data masakan memiliki sebuah controller yang bernama masakan control. Tujuan dari masakan control adalah untuk mendapatkan data dari data masakan yang berupa nama masakan dan bahannya. Masakan control digunakan oleh list masakan UI dan Masakan UI serta list solusi masakan UI.

Selain terdapat data masakan, terdapat juga turunan dari data masakan yang berupa bahan masakan. Bahan masakan berisi nama bahan dan nilai, pada nama bahan dibagi berdasarkan gizi bahan tersebut, yaitu karbohidrat, protein dan vitamin mineral. Untuk masingmasing gizi tersebut, terdapat nama, nilai dan jumlahnya. Bahan masakan memiliki dua controller, yaitu bahan control dan solusi control. Bahan control berguna untuk menampilkan data bahan pada list bahan UI, sedangkan solusi control digunakan untuk menghitung bahan dan menentukan nilai tertinggi pada bahan tersebut dan digunakan list solusi masakan UI. Penjelasan singkat tentang class diagram dapat dilihat pada Gambar 8. 


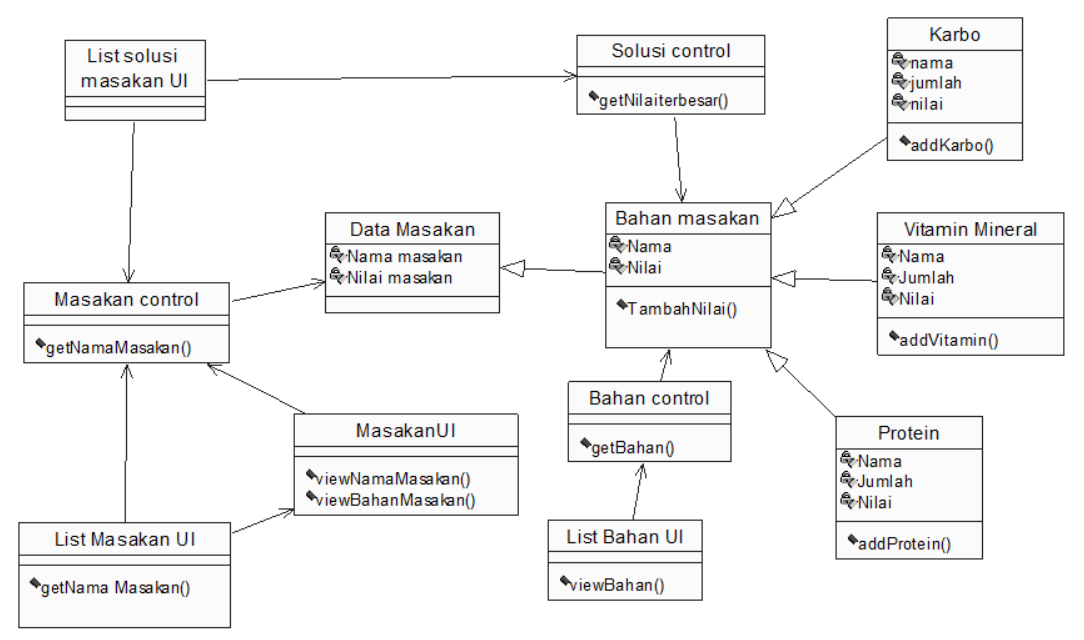

Gambar 8 Class Diagram

Perancangan pohon pada tiap masakan dibuat berdasarkan 3 kriteria, yaitu karbohidrat, protein, dan vitamin mineral. Tiap-tiap masakan dibagi 3 berdasarkan kriteria tersebut. Tiap kriteria diisi berdasarkan bahan resep masakan yang terkandung untuk masing-masing kategori gizi. Sama halnya dengan perancangan pohon inputan, yang berbeda adalah nama masakan dicari dengan perhitungan bobot kemiripan tertinggi.

\section{Hasil dan Pembahasan}

Aplikasi yang dibuat merupakan aplikasi mobile yang berisikan tentang panduan memasak. Panduan memasak dibuat sederhana dengan maksud dapat dipahami oleh semua kalangan. Untuk semakin membuat aplikasi ini tidak hanya sebatas memberikan panduan memasak, aplikasi ini menambahkan menu yaitu, menu memberikan solusi.

Penelitian ini berfokuskan pada menu pemberian solusi memasak dengan algoritma Extended Weighted Tree Similarity sebagai landasannya. Penyimpanan data masakan menggunakan fungsi Vector. Fungsi Vector sama dengan fungsi ArrayList, namun fungsi ArrayList tidak dapat digunakan pada J2ME.

Vector memiliki dua atribut utama yaitu, kapasitas dan penambahan kapasitas. Penambahan kapasitas menentukan berapa jumlah indeks yang akan ditambahkan jika indeks saat ini sudah tidak mencukupi [9].

Untuk mempermudah user, aplikasi dibuat dengan bantuan gambar yang berhubungan dengan isi menu tersebut. Fungsi yang digunakan adalah canvas, dengan adanya fungsi tersebut aplikasi dapat dimodifikasi dengan gambar dan diatur background warna tampilannya. Aplikasi ini berisikan beberapa menu, yaitu menu Resep Masakan, menu Solusi Masakan, dan menu Keluar, seperti pada Gambar 9(a).

Apabila user memilih menu Resep Masakan, aplikasi akan langsung memunculkan daftar menu masakan. Dengan bentuk list memudahkan user dalam memilih dan bisa langsung mengakses data tersebut, selain itu dalam list tersebut dilengkapi icon yang merupakan gambar dari hasil masakan. Bentuk list masakan dapat dilihat pada Gambar 9(b).

User dengan bebas memilih masakan yang tersedia pada aplikasi Cooking Smart. Ketika user memilih salah satu menu masakan yang ada, halaman tampilan akan berubah dengan tampilan menu masakan tersebut. Isi dari tampilan tersebut berupa bahan masakan dan cara membuat masakan serta ditampilkan gambar dari masakan tersebut. Tujuan dari gambar masakan adalah memberikan gambaran tentang hasil jadi masakan yang akan dibuat. Tampilan menu masakan dapat dilihat pada Gambar 9(c).

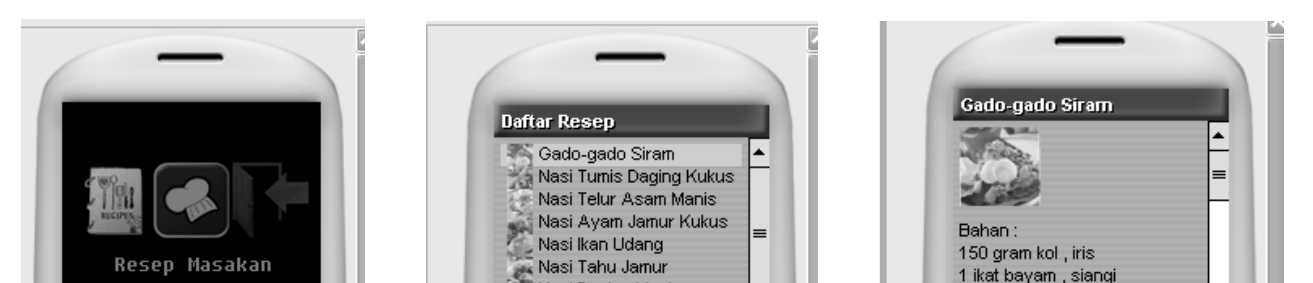


Gambar 9 (a)Tampilan Awal Menu Resep Masakan, (b) Form Daftar Resep Masakan, (c) Form Resep Masakan Gado-gado Siram

Untuk mempermudah user dalam memilih bahan masakan, pemilihan bahan digunakan checkbox sehingga user pun dapat memilih lebih dari satu bahan masakan. Tampilan list bahan masakan dapat dilihat pada Gambar 10.

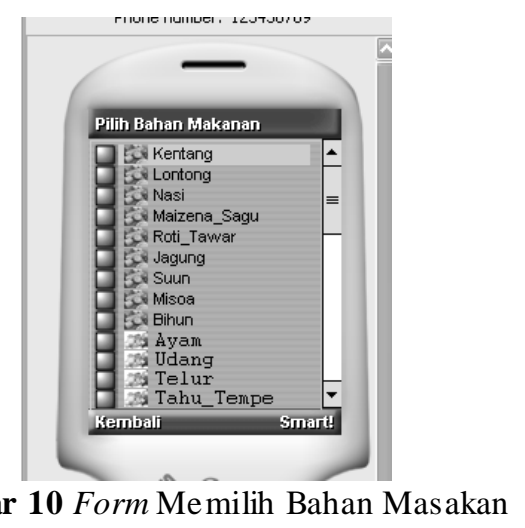

Untuk mempermudah cara perhitungan bobot perhitungan, nilai identifier antara masakan dan inputan user dikalikan terlebih dahulu. Dan bobot kemiripan akan didapat dari nilai perkalian antara bobot parent dan bobot identifier. Contoh menu Solusi Masakan dengan bahan nasi, jagung, ayam, selada dan tomat dapat dilihat pada Gambar 11(a) dan Gambar 11(b).

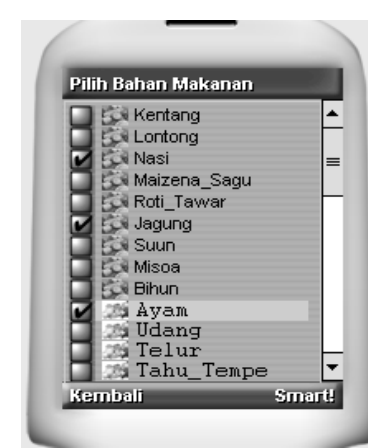

Gambar 11(a) Tampilan Memilih Bahan Nasi, Jagung dan Ayam

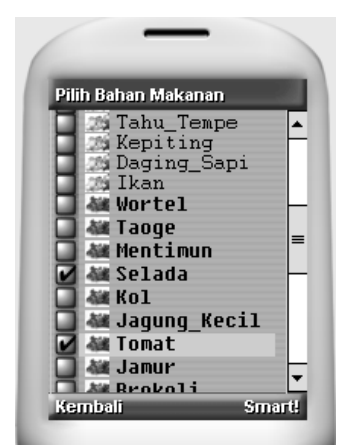

Gambar 11(b) Tampilan Memilih Bahan Selada dan Tomat

Gambar 16 merupakan contoh user yang sedang mencari solusi memasak dengan bahan nasi, jagung, ayam, selada dan tomat. Setelah selesai memilih bahan masakan akan muncul tampilan pada Gambar 12. 


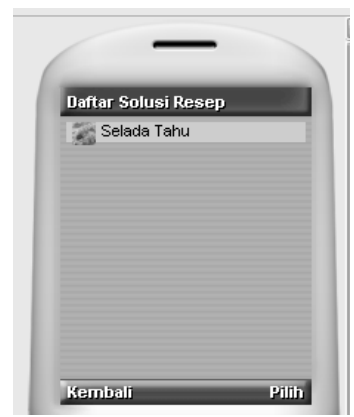

Gambar 12 Form List Resep Solusi Memasak

Gambar 12 merupakan hasil perhitungan Extended Weighted Tree Similarity yang telah berupa hasil akhir, yaitu resep masakan dengan nilai bobot kemiripan tertinggi. Resep solusi masakan dapat dalam jumlah banyak, tidak menutup kemungkinan hasil tertinggi suatu masakan adalah sama. Apabila user ingin melihat resep masakan yang menjadi solusi, user tinggal memilih button pilih dan resep masakan tersebut akan langsung keluar.

\section{Simpulan}

Aplikasi Cooking Smart dapat memberikan kemudahan bagi user untuk menggunakan aplikasi ini. Hal ini dikarenakan aplikasi diimplementasikan pada aplikasi mobile yaitu J2ME. Pemilihan platform java melihat dari banyaknya aplikasi mobile yang menggunakan platform java seperti Nokia, Sony Ericson dan Blackberry. Aplikasi mobile memberikan kemudahan dalam menggunakan di mana, kapan dan siapa saja.

Penerapan algoritma Extended Weighted Tree Similarity pada J2ME dengan fungsi vector memberikan kemudahan dalam membuat tree dan membandingkan antara tree utama dan tree inputan. Pemanfaatan fungsi vector dapat digunakan untuk menyimpan data masakan yang berupa bahan-bahan masakan. Bahan-bahan masakan tersebut dimasukkan dalam vector dan dibentuk menjadi pohon yang digunakan sebagai perbandingan.

Algoritma Extended Weighted Tree Similarity membantu dalam pemberian solusi resep masakan terbaik dengan berdasarkan bahan masakan yang dipilih. Hasil solusi tersebut didapat dari perhitungan nilai terbaik atas kemiripan bahan masakan yang telah ada dengan bahan masakan yang dipilih oleh user. Solusi masakan dapat digunakan sebagai panduan mencocokkan bahan yang dimiliki atau dikehendaki dikarenakan keterbatasan bahan masakan.

\section{Daftar Pustaka}

[1] Yulianti, Tjiong Debora, 2010, Perancangan Dan Implentasi Personalisasi Modul Similaritas Pencarian Lowongan Kerja, Universitas Kristen Satya Wacana

[2] Sarno, Riyanarto, dan Faisal Rahutomo, 2008, Penerapan Algoritma Weighted Tree Similarity untuk Pencarian Se mantik, Juti 7: 35-42

[3] Solihin, Firdaus, dan Riyanarto Sarno, 2006, Penerapan Arsitektur Agent Matcher Menggunakan Algoritma Extended Weighted Tree Similarity untuk Menyediakan Informasi yang Optimal pada Handheld Device, Se minar Nasional Pascasarjana VI 2006 :38-43

[4] Bp, Agung, Kodrat IS dan Adjie Wibowo. 2005. Simulasi Aplikasi Java 2 Platform Micro Edition (J2ME) - Java Midlet pada Jadwal Ujian. http:/www.elektro.undip.ac.id/ (dia kses tanggal 10 Februari 2011)

[5] Irawan. 2008. Java Mobile untuk Orang Awam. Palembang: Penerbit Maxikom

[6] Irawanto, Djon. 2007. Membangun Object Oriented Software dengan Java dan Object Database. Jakarta: PT Elex Media Komputindo 
[7] Nyura, Yusni, 2010, Pembuatan Aplikasi Pembelajaran Bahasa Inggris pada Handphone dengan J2ME, Jurnal Informatika Mulawarman 5:18-27

[8] Fatta, Hanif Al. 2007. Analisis dan Perancangan Sistem Informasi untuk Keunggulan Bersaing Perusahaan dan Organisasi Modern. Yogyakarta: C.V ANDI OFFSET (Penerb it Andi)

[9] Hakim, Rach mand S. dan Ir. Susanto, M. Si, 2009 , Mastering Java: Konsep Pemrograman Java dan Penerapannya untuk Membuat Software Aplikasi, Jakarta: PT Elex Media Ko mputindo 